\title{
Memory struggles: remembering the apartheid era by University of Natal medical alumni, 1990s to the early 2000 s
}

\author{
Vanessa Noble*
}

Becoming a doctor was not an easy feat for African, Indian and coloured students in apartheid South Africa. ${ }^{1}$ Indeed, the odds were heavily stacked against these students, from the racially-disadvantaged communities they grew up in; to the inferior schools they were allowed to attend; to the limited financial resources they had available to pay for their studies. Even for those who managed, despite the odds, to make it successfully to the tertiary level with passes in mathematics and science subjects necessary for entry into medical school, there was little in the way of choice for those wanting to study medicine in South Africa. When the University of Natal's Medical School (or the Durban Medical School as it became popularly known) first opened its doors in 1951, it was one of only three places in the entire country to offer a full biomedical qualification for black students. And after 1959, when the apartheid government required the medical schools at the Universities of Cape Town and the Witwatersrand to close their doors to black students (unless special ministerial permission was obtained first), Durban's Medical School became the main institution that provided such a training. This remained the case until the late 1970s when another institution - the Medical University of South Africa (MEDUNSA) - was opened north of Pretoria in Garankuwa for African students, and the 1980s when political and educational reforms allowed black students to apply once again to the country's historically white medical schools.

The author is a lecturer in Historical Studies in the School of Social Sciences at the University of KwaZulu-Natal. Her teaching and research focus on the history of health and healing issues in Africa more broadly, with a particular interest in historical developments within medical education and biomedical health care services in South Africa. She is grateful for the comments received on earlier drafts of this article from many people at the University of KwaZulu-Natal History and African Studies seminar in Durban; the "Production of Knowledge in Africa" conference in 2009 at the University of Michigan, Ann Arbor; the "Health Care in Africa" conference at the University of Basel in Switzerland in 2011; and at the 2014 "Memory in Africa" conference at the University of KwaZulu-Natal in Durban. David William Cohen, Nancy Rose Hunt, Julie Parle and Catherine Burns deserve special thanks for their helpful feedback on this article, as do the anonymous peer reviewers of this article.

How to cite this article:

Noble V. Memory struggles: remembering the apartheid era by University of Natal medical alumni, $1990 \mathrm{~s}$ to the early 2000s. Historia. 2015; 1(1), Art. 21 pages. http://dx.doi.org/10.17159/2309-8392/2015/v60n1a1

1. Terminology has a contested history. Under apartheid, South Africans were classified into one of four "race" groups. In this article terms such as "Bantu"/"African", "Asian"/"Indian", "coloured" and "European"/"white" will be used to denote specific groups of people as designated by the state, but also used by ordinary people. While I recognise that racial classifications are simplistic and contentious social constructions, their usage had real socio-economic and political effects before 1994, and still has resonance today. Use of these terms as descriptive and analytical categories is a necessary part of understanding any history dealing with South Africa's history. 
This article steps back from trying to capture Durban Medical School's social history, to reflect on the issue of memory, especially the constructed nature of memories produced by alumni who studied and worked at this institution. While collecting research material in the early 2000 s for a doctoral thesis that focused on the history of apartheid-era medical education in South Africa, ${ }^{2}$ I noticed how certain versions of the history of Durban's Medical School were publicly privileged and frequently remembered in the early post-apartheid years. Indeed, narratives emphasising "unity in adversity" in particular, as well as ones foregrounding the importance of students' involvement in the anti-apartheid "struggle", flooded my vision in a variety of written (published) sources, such as University of Natal publicity and communications division publications, Faculty of Medicine newsletters and newspaper articles. These types of narratives were also repeated in some of the interviews done with alumni by the author at the time. ${ }^{3}$ A number of questions stemmed from this research: Why were these particular narratives emphasised and what work did they do for the people remembering them? What narratives were concurrently suppressed by the promotion of these narratives? And did the production of these narratives shift over time?

To answer these questions, a historically-driven analysis will be used, as well as analysis of a variety of oral and written sources. The first part of this article will examine, as alluded to above, some of the common, celebratory memory narratives produced by Durban Medical School alumni in the 1990s period. This will be contrasted in the second half of the article with a focus on the shifting trend towards the construction of alternative memory narratives in the early 2000s. These narratives emphasised memories of "racial" tensions and divisions between Africans and Indians; two groups who had been brought together in the confines of this Medical School and ultimately came to make up the bulk of students studying in Durban during the apartheid years. ${ }^{4}$ Key reasons for the promotion of certain memories and the simultaneous silencing of others at certain times will be analysed. So will the effects of changing historical contexts on the construction of memory narratives. It is hoped that analysis of these issues will open up new terrain for the researcher exploring institutional histories.

2. My doctoral dissertation on the education of black doctors in South Africa was recently published as a book. See V. Noble, A School of Struggle: Durban's Medical School and the Education of Black Doctors in South Africa (University of KwaZulu-Natal Press, Scottsville, 2013).

3. This article draws on interviews conducted for my doctoral research, which includes about 30 qualitative, in-depth interviews (some requiring follow up interviews) with semistructured questions, which I conducted in South Africa in the early 2000s. Although this sample is not representative of the many students who studied at the Durban Medical School during the apartheid years, I was mindful of conducting interviews with a variety of people from different cohorts, but also from different "race" groups, class backgrounds and gender perspectives to try to get at a diversity of experiences. All interviews quoted in this article were conducted by the author, unless explicitly stated otherwise.

4. African applicants came from across South Africa, while Indian applicants were mainly from the province of Natal. The number of students coming from racially-mixed or coloured families always remained low, rarely exceeding five or six per annum. Nelson R. Mandela School of Medicine, Durban (hereafter NRMSM) Administration Office, Faculty of Medicine Annual Registrations, 1957-2003. 


\section{The 1990s: common memory narratives about studying medicine in Durban}

While doing research on alumni experiences of studying medicine in Durban, I was struck by the uncanny similarities in what individuals recorded in their 1990s era public narratives. For example, in 1991, an apartheid-era medical graduate, U.G. Lalloo, recorded the following about his alma mater in a university produced anniversary publication:

The celebration of the 40th anniversary of the Medical Faculty takes place in a momentous period in the political history of South Africa. The Faculty has been a significant barometer of black politics in this country for decades. Besides producing graduates who have excelled in all spheres of medicine, locally and internationally, the Faculty also has the distinction of having produced many leaders who were in the forefront of the struggle for political freedom in South Africa. ${ }^{5}$

A similar perspective was published a few years later by M.M.R. Belle, another apartheid-era medical alumnus, in an article written in a 1995 university graduation booklet:

Alan Taylor Residence ${ }^{6}$ was a hive of social, academic and political activity. ... The 1976 Soweto student uprisings, the death of Steve Biko in detention, the banning of all black political and student organisations and the attempted whole scale exclusion of African students from the Medical School, set a new political climate. The national school boycotts of 1980 further aggravated the situation and led to the graduation boycotts at the Medical School. These and other events countrywide aggravated a scenario of ceaseless political campaigns and more profound Residence activity that culminated in some of our students and graduates going into exile and others being imprisoned. All this contributed to making April 27, 1994 possible in South Africa. ${ }^{7}$

Indeed, the common thematic element of students' involvement in antiapartheid "struggle" activities, which led to hardships but also contributed to political freedom in South Africa, is evident in many written narratives produced by alumni in various university publications, but also in newspaper articles printed in the 1990s, and even through to the early 2000s. ${ }^{8}$ So is the theme of students' "unity in adversity" against their apartheid enemies:

When in 1950 the apartheid government created a "black faculty" in a "white institution" it shaped an environment ordained to nurture a commonality of purpose that would far exceed its expectations. For not only was the Medical School of the University of Natal destined to produce doctors of international quality, it was also to provide the anvil on which the tools to fight its creator would be fashioned. ... [Its

5. "Message from $\mathrm{Dr}$ U.G. Lalloo, President, Medical Graduates Association", in The University of Natal Medical School 1951-1991: Meeting the Challenge of Change (Communication and Publicity, University of Natal, 1991).

6. The Alan Taylor Residence - or ATR for short - was the main residence for Durban's medical students.

7. "Reflections on Life at the Medical School by Dr M.M.R. Belle", in University of Natal Medical School: Reconciliation Graduation Booklet (Communication and Publicity, University of Natal, 1995), p 13.

8. See for example, newspaper articles, such as "University of Natal Reconciliation Graduation Ceremony to be Held", Daily News, 30 November 1995; G. Stolley, "Healing Old Hurts", Daily News, 6 December 1995; P. Leeman, "Milestone in Medical School's Proud History", Mercury, 25 January 2000; "Medical School to Celebrate Fifty Years of Achievement", Berea Mail, 7 April 2000; and M. Peters, "Hallowed Halls of Medicine: Fifty Years Old with an Illustrious List of University Graduates", Independent on Saturday, 29 July 2000. 
students] came from disparate backgrounds, but they were united in adversity. ... The corridors of the University's Faculty of Medicine became a hub of political activity, and the Alan Taylor Residence at Wentworth, the target of many raids by the security police, provided an uneasy setting for the planning of subversive actions against the state. As a result, the Medical School quickly became synonymous with the struggle against apartheid... ${ }^{9}$

This 50th anniversary publication in fact includes articles written by male and female alumni, by graduates coming from diverse "racial" backgrounds, not to mention, from different generations, though highlights similar narratives, despite the change over time. Even a first generation doctor, who graduated in the 1950s, constructed and recorded a similar story:

I look back at the early years of the institution when political interference and harassment was commonplace. I remember with pride the single-mindedness and fixity of purpose that drew us together. Despite our disparate backgrounds and cultures we soon because united in adversity and developed into a closer knit community with a brand of camaraderie that I believe have not been seen at this institution again. ${ }^{10}$

Interviews conducted by the author with alumni in the early 2000 s also produced similar narratives, as the following two quotations, produced by two African medical graduates, affirm:

I lived at Alan Taylor Residence. ... It's amazing ... how we remember things and places that really in fact leave much to be desired. But I don't think ... there's any time of my study here that I enjoyed more than in that place. It was a dingy place, it was a barracks ... but you know the one thing good about it is that it really built a spirit of unity; it built a spirit of oneness ... it brought us closer together ... you know Indians, Coloureds and Africans. ... [W] we were really ... a very close-knit family.... And out of that came ... the Black Consciousness Movement of which Steve Biko was in fact among the pioneers. ${ }^{11}$

We stayed at the old Alan Taylor Residence... The conditions were actually horrible... [but] there was a strong spirit of comradeship with the people who all lived and studied there... I think as we got along, we made friendships across these black groups because I think people were kind of bound together by the perception of apartheid and the need to fight it... [as] a common enemy... ${ }^{12}$

These examples provide just a small taste of common themes that were repeated in written and oral accounts constructed by a diverse array of Natal medical alumni in the early years of the post-apartheid era. Some people, as evinced in the quotations provided above, even used similar phrases that sounded almost rehearsed when read or heard. And these comparable statements were produced despite the fact that alumni constructed their accounts on separate

9. J. Moodley and S. Maharaj (eds), "History's Hand in the Shaping of the Medical School", in University of Natal Nelson R. Mandela School of Medicine: 50 Years of Achievement in Teaching, Service and Research (Communications Office, University of Natal Nelson R. Mandela School of Medicine, 2001), p 9.

10. "The Early Days: Dr Thaven 'B.T.' Naidoo's Story" in Moodley and Maharaj (eds), University of Natal Nelson R. Mandela School of Medicine: 50 Years of Achievement, pp 13-15.

11. Interview conducted with M.J. Matjila, Durban, 11 July 2003.

12. Interview conducted with M.J. Ndlovu, Durban, 14 August 2003. A similar perspective was also promoted by a woman alumnus - May Mashego - whom I interviewed in Durban on 7 October 2003. 
occasions, or that they came from diverse graduating cohorts extending from the 1950 s through to the early 1990s.

In recent years, many scholars working in the growing and interdisciplinary research fields of oral history and memory studies have contributed fruitful theoretical discussions about the potential and pitfalls of using memories for the writing of history. ${ }^{13}$ This has played out in different ways among scholars in the social history tradition, and those influenced by post-structuralism. While conventionally, social historians have tended to view memories as objective or factual sources to help them understand ordinary people's experiences "from below", ${ }^{14}$ scholars influenced by post-structuralism have insisted on recognising all narratives (including memories) as creative productions needing careful deconstruction to comprehend their meanings and silences. ${ }^{15}$ This latter group has, in effect, pushed scholars to reflect more carefully about the role played by producers of particular narratives, including when and why (i.e. the intended motives or purposes) their narratives were produced. This argument, for example, was developed by anthropologist Michel-Rolph Trouillot who asserted in his book Silencing the Past: Power and the Production of History that supposed "facts" collected about the past are never meaningless. Indeed, "they become facts only because they matter in some sense, however minimal" to someone. ${ }^{16}$ For Trouillot, analysis of the processes and conditions (including the "differential exercise of power") that enables the production of some memories and the silencing of others is essential, as is consideration of the relational aspects of all memory narratives. ${ }^{17}$

Indeed, the production of memories reveals a great deal about a person's relationship to broader social groupings. Some scholars, such as sociologist Maurice Halbwachs and social anthropologist Paul Connerton have examined how remembering is not merely a process located in the individual mind. Memories are "collective" in the sense that individuals try to locate their memories in broader social frameworks, as well as in dialogue with other people. ${ }^{18}$ This helps people create a sense of social cohesion, as well as harmony, and provides a way to

13. See for example, S. Radstone and B. Schwarz (eds), Memory: Histories, Theories, Debates (Fordham University Press, New York, 2010).

14. Social historians focused on assessing the reliability or truthfulness of memories as factual evidence distorted by biases and exaggerations. See for example, J. Sharpe, "History from Below", in P. Burke (ed.), New Perspectives on Historical Writing, Second Edition (Polity Press, Cambridge, 2001), pp 25-42; E.P. Thompson, The Making of the English Working Class (Vintage Books, New York, 1963); and P. Thompson, The Voice of the Past: Oral History, Third Edition (Oxford University Press, Oxford and New York, 2000), especially chapters 4 and 5 .

15. See for example D.W. Cohen, "The Undefining of Oral Tradition", Ethnohistory,36, 1, 1989; D.W. Cohen, The Combing of History (Chicago University Press, Chicago and London, 1994) and C. Hamilton, "'Living by Fluidity': Oral Histories, Material Custodies and the Politics of Archiving", in C. Hamilton, V. Harris, J. Taylor, M. Pickover, G. Reid and R. Saleh (eds), Refiguring the Archive (David Philip, Cape Town, 2002).

16. M.R. Trouillot, Silencing the Past: Power and the Production of History (Beacon Press, Boston, 1995), p 29.

17. Trouillot, Silencing the Past, pp 11-12 and 25. Also see D. Moore and R. Roberts, "Listening for Silences", History in Africa, 17, 1990, pp 319-325.

18. P. Connerton, How Societies Remember (Cambridge University Press, New York, 1989) and L.A. Coser (ed.), Maurice Halbwachs: On Collective Memory (University of Chicago Press, Chicago and London, 1992). Also see A. Green, "Can Memory Be Collective?" in D.A. Ritchie (ed.), The Oxford Handbook of Oral History (Oxford University Press, Oxford and New York, 2011). 
make sense of and to gain meaning from their life experiences. What is more, memories are often arranged to make them more relevant to the particular present of the person remembering them. ${ }^{19}$ This point was aptly captured by African oral literature specialist, Isabel Hofmeyr in her book, We Spend our Years as a Tale that is Told: Oral Historical Narrative in a South African Chiefdom, where she wrote:

\footnotetext{
Not only do historical narratives refer to the past and mediate an understanding of the past through their form; the stories and their tellers also pass through time and are shaped by its often precipitously changing circumstances. Stories, then, comment on the passing of time and times past. ${ }^{20}$
}

Thus, studying people's memories tells us as much about the past as it does about the present. Undeniably, the past and present are closely intertwined in shaping how, when and why people remember.

The alumni quotations included earlier certainly give us information about the history of Durban's Medical School. However, these cannot be treated naively as transparent historical facts that have simply been recovered for use by the historian. Taking analysis beyond mere coincidence to scrutinise why these memories were similarly constructed requires consideration of motives. For some alumni, being employed at the same institution whose history they were commenting on might have been a real influence on fashioning their narratives. Many might not have wanted to alienate their employer by being critical in public; while feelings of loyalty or duty could have compelled others to remain silent on contentious issues. Moreover, the desire to gain recognition for hardships endured and contributions made might have been key factors. This would have been especially the case among older generations, such as those in retirement age, but also among those wanting to take general stock of their lives. As oral historian Alessandro Portelli has argued, memories tell us a great deal about people's attitudes and values as well as what their needs and desires are at a particular moment: "It is not just what people did, but what they wanted to do, what they believed they were doing, and what they now think they did". ${ }^{21}$

The influence of broader collective memory frameworks, as well as the politics of the present, would have influenced the way Durban medical alumni constructed their memories too. Indeed, the narratives referred to in this article were recorded in the post-apartheid era; a crucial period of transformation in South Africa's history. The decade of the 1990s, especially the years immediately after the 1994 elections, were concerned with building a new, unified nation through reconciliation. During this period, the first democratic government, led by President Nelson R. Mandela, worked energetically to promote a hegemonic multi-cultural "rainbow nation" imagery that was inclusive of all people. ${ }^{22}$ Geared towards

19. Trouillot, Silencing the Past, pp 12-14.

20. I. Hofmeyr, We Spend Our Years as a Tale that is Told: Oral Historical Narrative in a South African Chiefdom (Heinemann, Portsmouth: $\mathrm{NH}$ and Witwatersrand University Press, Johannesburg, 1993), p xi.

21. A. Portelli, "What Makes Oral History Different", in R. Perks and A. Thomson (eds), The Oral History Reader, Second Edition (Routledge, London and New York, 2006), pp 36-37.

22. For more on the ANC's collective nation-building memory narratives in South Africa, see for example, T. Lodge, Politics in South Africa: From Mandela to Mbeki (David Philip, Cape Town and James Currey, Oxford, 2002); R.A. Wilson, The Politics of Truth and 
healing long established racial differences that had divided the population for decades, it also celebrated and commemorated what it regarded as "heroes of the anti-apartheid struggle". ${ }^{23}$ These teleological "grand narratives" were promoted on many fronts, including the political sphere (e.g. the work of the Truth and Reconciliation Commission), in the school curriculum, in the arts and sports arenas, as well as in the burgeoning heritage sector. ${ }^{24}$ They were also encouraged by universities in the 1990s, including the University of Natal.

Certainly, during this period, unlike in earlier decades when this University's publications included little (if any) focus on anti-apartheid political matters, public support for the new political dispensation saw the alignment of the University of Natal's institutional memory with unifying and reconciliatory "rainbow nation" building ones, as well as ones emphasising this institution's role as a leader in the "struggle" against apartheid, and in initiating educational transformations in line with government policies in the post-apartheid era. ${ }^{25}$ As evinced in many of the already mentioned University of Natal commemorative publications, which were sponsored and vetted by the university before they were released to the public for consumption, ${ }^{26}$ these alignments were also made explicit in statements captured by those in management, such as the university's annual reports by the vicechancellor and principal, as well as in Council minutes from the 1990 seriod. $^{27}$

Whether done consciously or not, Durban medical alumni would have been influenced by these broader and overlapping societal and university memory frameworks. In an era of widespread nation-building euphoria, few would have

Reconciliation in South Africa: Legitimizing the Post-Apartheid State (Cambridge University Press, Cambridge, 2001); and H.E. Stolten (ed.), History Making and Present Day Politics: The Meaning of Collective Memory in South Africa (Nordiska Afrikainstitutet, Uppsala, 2007).

23. S. Marschall, "Pointing to the Dead: Victims, Martyrs and Public Memory in South Africa", South African Historical Journal, 60, 2008, pp 103-123.

24. See for example, S. Nuttall and C. Coetzee (eds), Negotiating the Past: The Making of Memory in South Africa (Oxford University Press, Oxford and New York, 1998); A.E. Coombes, History after Apartheid: Visual Culture and Public Memory in a Democratic South Africa (Duke University Press, Durham and London, 2003); G. Baines, "The Master Narrative of South Africa's Liberation Struggle: Remembering and Forgetting June 16, 1976", The International Journal of African Historical Studies, 40, 2, 2007, pp 283-302 and S. Marschall, Landscape of Memory: Commemorative Monuments, Memorials and Public Statutory in Post-Apartheid South Africa (Brill, Leiden, 2010).

25. Perusals of University of Natal communication and publicity commemorative publications between 1948 and 2005, which are housed at the University of KwaZulu-Natal Archives Pietermaritzburg (hereafter UKZNA) campus, highlight clearly this trend. The most likely reason for the lack of discussion of anti-apartheid political activities in the pre-1990s period, which certainly took place on occasion amongst its staff and students (and often quite frequently on this university's medical campus), was that this university did not want to publicise activities that might have jeopardised its state subsidies.

26. For more on this, see documents in UKZNA, C83/1/1, University Publications Committee, 1987.

27. See for example, UKZNA, AR1/3/1-14, Annual Report of the Vice-Chancellor and Principal, Part I, 1988-2001, "Report of the Vice-Chancellor and University Principal", in Annual Report of the Vice-Chancellor and University Principal, University of Natal (Part I: 1994), $p$ 1. Also see Part I: 1995, pp 1-3 and Part I: 1996, p 1. Furthermore, see UKZNA, C10/11/136 Council Minutes, 25 June 1993 to December 1998; "Minutes of a Meeting of the University Council held in Durban on 8 December 1995"; Annexure 1 (Section 2), "University of Natal Medical School Reconciliation Ceremony Address by Professor B.M. Gourley", attached to Vice Chancellor's Report to Council, December 1995. 
wanted to be identified as critics with dissenting voices, while others would have found this framework useful to make sense of their lives. What is more, association with these romanticised unity and liberation focused narratives would have enabled some individuals to gain greater acceptance, and even political affirmation in the new social order. As Sabine Marschall has shown in her article "Pointing to the Dead: Victims, Martyrs and Public Memory in South Africa", reference to "popularly rooted and emotionally charged past events and persons" was a way to "opportunistically" enhance the public profile and derive legitimacy for many individuals preparing themselves for entry into post-apartheid political careers. ${ }^{28}$ A quick inspection of newspaper articles in the 1990s and early 2000s reveal how a number of Durban medical graduates went on to fill a variety of positions in post-apartheid governments. ${ }^{29}$

\section{Remembering to forget}

The construction of individual narratives to align with larger unity and struggle collective memory frameworks, however, represents only part of the complex history of students' interactions at the University of Natal's Medical School. While the promotion of harmonious and celebratory narratives might have been prevalent in the 1990s, divergent memories also existed amongst alumni, though these might not have been vocalised in public. In the second part of this article, consideration will be made of the other side of the story, in other words, what the promotion of these common memories concealed, including analysis of some of the tensions and schisms that caused disunity and conflicts among apartheid-era students. Furthermore, this section will analyse how a changed historical context encouraged the production of alternative memory narratives amongst alumni.

Africanist historical anthropologist David William Cohen has encouraged scholars to think more critically about the act of "forgetting", usually regarded as the opposite side of remembering. However, for Cohen, the act of forgetting is much less forgetful than expected. In his book The Combing of History, Cohen argues that "Remembering and forgetting are not opposed and reciprocal programs; they are deeply intertwined". ${ }^{30}$ Scholars must therefore study the construction of memories not just for what is recollected, but for what is suppressed at any given historical moment. This point was echoed by Trouillot who asserted that all narratives are made up of both "presences and absences", neither of which is neutral or natural. Indeed - and obviously referring to individuals without physical brain injuries or memory affecting diseases - people engage actively in the practice of recollection, as well as suppression. This makes mentions and silences the "dialectical counterparts of which history is the synthesis". ${ }^{31}$ For these scholars, memories should be studied as constructed entities both for what they reveal, but also what they obscure. ${ }^{32}$

Moreover, though certain memories can be stifled in public at particular historical moments, or even for long periods of time, alternative memories can and often do remain active in the minds of individuals. They are also produced by

28. Marschall, "Pointing to the Dead", p 109.

29. For examples, see newspaper articles already noted in footnote 8 .

30. Cohen, The Combing of History, pp xxiv, 22.

31. Trouillot, Silencing the Past, pp 48-49.

32. Similar points were also made by Moore and Roberts, "Listening for Silences", p 321. 
people in private spaces, or as what oral historian Alistair Thomson has referred to as, smaller "particular publics which affirm our identities and the way we want to remember our lives". ${ }^{33}$ Additionally, their suppression is not ensured over time. Repressed memories sometimes have the power to erupt into the larger public domain in altered historical circumstances, and can cause a substantial change in the overall collective memory narratives produced.

This was the case for alumni of Durban's Medical School. In July 2000, powerful alternative memories about studying medicine at this institution were made audible in a very dramatic fashion at the School's 50th anniversary celebrations. This event was attended by many guest dignitaries, including former president Nelson R. Mandela; the deputy president at the time, Jacob Zuma; the Zulu king, Goodwill Zwelithini; as well as other notable politicians, educators and business people, such as Drs Nkosazana Dlamini Zuma, Zweli Mkhize and Ben Ngubane (the last three of whom also trained as doctors in Durban), to mention but a few. This glamorous event, which was hosted in the Durban City Hall, became the unexpected occasion for a number of alumni to share their memories, which explicitly contradicted the common reconciliation, unity and struggle memory narratives in circulation in the years leading up to this time. ${ }^{34}$

One of the biggest issues brought up for debate at this event were the racial tensions and schisms that had long festered at this Medical School and divided African and Indian South Africans in both the apartheid and post-apartheid periods. In a speech that focused on memories of discriminatory and unequal treatment afforded Africans as both students and staff in its 50 years history, ophthalmologist Kgotsi Letslape asserted that it was now time "for the systematic persecution of our people to stop!" ${ }^{35}$ As it turned out, Letslape's inflammatory statements were the beginning of an avalanche of memories focused on race and racism issues, which were captured in statements made in the local press in the months and years that followed. ${ }^{36}$ These speeches and articles highlight how alumni did not experience their time at the Medical School in the same way, nor did they suffer or struggle in the same way. Instead, as we shall see below, students' interactions during the apartheid period were messy and complicated;

33. A. Thomson, "Anzac Memories: Putting Popular Memory Theory into Practice in Australia", in R. Perks and A. Thomson (eds), The Oral History Reader, Second Edition (Routledge, London and New York, 2006), p 245. Also see P. Thompson, "Evidence", in The Voice of the Past: Oral History, Third Edition (Oxford University Press, Oxford and New York, 2000), p 133.

34. See the audio-visual source housed at the UKZN, E.G. Malherbe Library, entitled University of Natal Nelson R. Mandela School of Medicine, 50th Anniversary Banquet (Audio-Visual Centre, University of Natal, 29 July 2000) and Moodley and Maharaj (eds), University of Natal Nelson R. Mandela School of Medicine: 50 Years of Achievement.

35. Similar points were also made at the 50th anniversary by ANC politician Dr Zweli Mkhize, who studied at this school in the early- to mid-1980s.

36. See for example, P. Leeman, "University's Medical School Criticised”, The Mercury, 31 July 2000; M. Nyoka, "Day of Shame for NU Medical School: Selfishness has Sullied the Glorious History of a Fabled Institution", The Mercury, 11 August 2000; I. Bechoo, "Med School Row Goes on: Action Committee Walks out of Meeting", Daily News, 12 March 2001; N. Mchunu, "Medical School Row Widens: Ten Indian Staff Suspended over Racism Claims, Official Says", Weekend Witness, 8 October 2005; A. Bolowana, "Allegations of Discrimination at School of Medicine: Ex-Students Back Racism Report", The Mercury, 10 October 2005; D. Potgieter, "University of Dirty Tricks", The New Age, 6 January 2012; D. Potgieter, "Talk of Racism and Hidden Agendas", The New Age, 6 March 2012; S. Coan, "Doctors Seek Probe into UKZN", Weekend Witness, 2 June 2012. 
and marred by strains and divisions, which also, importantly, continued into the post-apartheid period.

\section{The early 2000s: alternative memories about studying medicine in Durban}

A significant site of student interactions, but also one that provoked dissonance was the school's Alan Taylor Residence (or ATR); an army-like barracks or dormitory which housed the majority of medical students during the apartheid years. ${ }^{37}$ Located some ten kilometres away from the Medical School and in a highly polluted industrial area (close to an airport and oil refinery), its inferior facilities and unsuitable geographical location did not help to ease the school's diverse student body into university life. ${ }^{38}$ Brought up in racially-segregated communities in apartheid South Africa, and having gone to separate schools, this residential arrangement provided the first opportunity for many African, Indian and coloured students, as well as male and female students from these "race" groups, to live, study and socialise together. However, while this close contact allowed some students to forge strong personal bonds and laid the foundations for genuine and enduring friendships, ${ }^{39}$ it also produced tensions amongst students, which played themselves out in social, educational and political ways.

Personality differences would certainly have influenced students' interactions at the individual level, while at the group level; there would have been many causes for dissension in the ranks. Factors linked to different class backgrounds and age cohorts, as well as diverse cultural practices and beliefs produced tensions amongst students at various times during the apartheid years. So too did gender tensions. Indeed, analysis of archival and oral records highlight that Durban's Medical School and residence environment - both of which were dominated numerically by men - reflected a masculine culture with sometimes blatantly sexist attitudes and values that worked to discomfort or marginalise women. ${ }^{40}$ These included, for example "womanising" practices instigated by male students during social occasions such as orientation; sexualised comments and jokes about women's "inferior" capabilities that were spoken or printed in student publications; while academic and student organisational networking activities centred mostly around men also sidelined or excluded women. ${ }^{41}$

37. National Archives of South Africa (hereafter NASA), Secretary of Union Education (UOD), 56, U3/26/4/5, University of Natal Building Grants and Loans for Medical School NonEuropeans, Letter from E.G. Malherbe (UN Principal) - the Secretary for Public Works, Pretoria re "Wentworth Camp: Proposed Non-European University College", 14 August 1947.

38. See Noble, A School of Struggle, chapter 4.

39. "Whites and Indians Opposed Apartheid of the Medical School", Natal Witness, 7 September 2000; Interviews conducted with B.T. Naidoo, Durban, 15 September 2003; ZM, Durban, 11 September 2003; and KM, Durban, 14 November 2003.

40. Of the 2413 students who graduated from the Medical School between 1957 and 1994, $77.12 \%$ were men and only $22.88 \%$ were women. It was only in the transformation-focused years of the 1990s and 2000s that gender parity was achieved at the Medical School. See NRMSM, Faculty of Medicine Annual Registrations and Graduations, 1950s-2005. Also see Watts, "Black Doctors, Part I: The Students", pp 37-38.

41. In addition to comments made about gender inequalities experienced by women students in interviews conducted with M.J. Matjila, Durban, 22 September 2003; M. Mashego, Durban, 14 and 18 October 2003; and V. Wilson, Durban, 6 November 2003. Evidence is also plentiful in archival sources, such as student publications: UKZNA, MQ 1/1/1-5, "Analysis of Women," The Amoeba,1, 2 (12 October 1953); board minutes: NRMSM Administration Office, "Memorandum from the MSRC to Faculty of Medicine Board re Other 
Furthermore, racial inequalities, which form the main focus of the last part of this article, caused deep divisions and tensions amongst students during the apartheid years. As early as the mid-1970s, University of Natal based social scientists, drawing on medical student interviews and questionnaire data for a research project on this institution's medical school, found that many students "did not mix easily", that friendships often occurred along "race" lines, and that friction or indifference between Indians and Africans was commonplace. ${ }^{42}$ These issues were discussed by a number of alumni during interviews conducted in the early 2000s, when asked to comment on the outcomes of the speeches and events after the 50th anniversary event. While some expressed discomfort talking about race and racism issues, ${ }^{43}$ many others produced memories suggesting a deep sense of racial discord that ran in stark contrast to the romanticised unity narratives that were promoted in the 1990s. As one alumnus, who preferred not to have his name used, told me:

There was very little social contact between Indian and African students ... despite the fact that they stayed in the same residence ... As a group, I think we sort of fairly kept to each other you know, kept apart. I don't think there were many Africans who had close Indian friends or coloured friends. I mean I think it was institutionalised in terms of their upbringing. ... [S]o you know everybody sort of tended to keep to themselves. ${ }^{44}$

K.P. Naidoo, a student whose studies were interrupted in the 1980 s by financial difficulties, concurred:

People lived apart and they hated each other for so long ... [and] now for a few years [at the Medical School] to say, you know, "shake hands and love each other",

Student Problems", Faculty of Medicine Board minutes, 2 February 1987, p 5. See also interviews conducted by other researchers, for example, University of the Witwatersrand, South African History Archive (hereafter WITS SAHA), South African Political Materials 1964-1990, Karis-Gerhart Collection, Part I: Interviews, Folder 41, Zuma, Nkosazana Dlamini, London, 3 July 1988, p 14. Also in published works penned by Durban alumni, such as D. Padayachee, What's Love Got to Do with It? And Other Stories (COSAW Publishing, Johannesburg, 1992), pp 153-55; M.W. Makgoba, Mokoko: The Makgoba Affair: A Reflection on Transformation (Vivlia Publishers, Florida Hills, 1997), pp 32-35; and M. Ramphele, "The Dynamics of Gender within Black Consciousness Organisations: A Personal View", in B. Pityana, M. Ramphele, M. Mpumlwana and L. Wilson (eds), Bounds of Possibility: The Legacy of Steve Biko and Black Consciousness (David Philip, Cape Town; Zed Books, London; and New Jersey, 1991), pp 214-215, 219 and 226.

42. H.L. Watts, "Black Doctors: An Investigation into Aspects of the Training and Career of Students and Graduates from the Medical School of the University of Natal, Part I: The Students", Institute for Social Research, University of Natal, 1975, pp 24, 41; and H.L. Watts, "Black Doctors: An Investigation into Aspects of the Training and Career of Students and Graduates from the Medical School of the University of Natal, Part II: The Graduates", Institute for Social Research, University of Natal, 1976, p 13.

43. For example, interview conducted with KM, Durban, 14 November 2003.

44. Interview conducted with TM, Pretoria, 21 August 2003. Other doctors raised similar points, such as those expressed in interview conducted with M. Mashego, Ashburton, 7 October 2003; and P. Govender, Questionnaire, 2003. Questionnaires were sent to alumni who resided overseas to gauge their opinions, but few alumni responded to these questionnaires. 
that's very artificial and unnatural ... You can't just wish [the divisions] away over a few years. ${ }^{45}$

One professor, who worked at the Medical School during the apartheid period, and still worked at this institution at the time of his interview, told me how African and Indian students still sat amongst students of their own "race" groups in the cafeteria during lunch breaks as they did during apartheid: "on the whole the Africans sit together, the Indians sit together and that's the way it's always been..."46

Others recalled strains that stemmed from rivalries amongst students generated by the apartheid state's Bantu Education policies. ${ }^{47}$ Skewed resource allocations in favour of whites, followed by Indians and coloureds, and lastly Africans, produced blatant educational inequalities on a sliding scale, which made it harder for Africans to succeed academically. ${ }^{48}$ Only a small number reached the secondary level, and even fewer passed matric with high enough marks, as well as passes in mathematics and science subjects necessary for medical school. Thus, students reached the tertiary level with qualitatively different educational experiences, which also placed them in unfair competition with one another. In his oral testimony in the 2000s, African alumnus, S.B. Pitsoe told me that most African students of his generation (the early 1960s) were "disadvantaged" as they had reached medical school without sufficiently developed practical skills in science. Indeed, as Pitsoe recalled, enrolment at the Medical School "was the first time some of our people saw a Bunsen burner or a beaker ... So now we were competing with ... Indians and coloureds who came from better schools". ${ }^{4}$

Adding to these educational strains were situations where African students failed their medical courses in larger numbers, leading to a higher overall drop-out rate during the apartheid years. ${ }^{50}$ This promoted resentment amongst many Africans who felt that their Indian colleagues were treated more favourably by their lecturers, as was captured by Bongiwe Bolani, a nurse who worked at the Medical School's teaching hospital in the 1950s. Bolani remembered hearing heated discussions amongst medical students (including her husband and his friends) about the high failure rate and poor relations between many Indian and African students:

African students seemed to think it was mostly black [African] people who failed. I knew black students who did not feel good about Indians. Africans thought Indians

45. Interview conducted with K.P. Naidoo, Durban, 4 June 2003. Similar points were expressed in interviews with Y.K. Seedat, Durban, 7 July 2003; M. Mashego, Durban, 7 October 3003; and N. Mahlaba, Durban, 7 June 2004.

46. Interview conducted with D. Pudifin, Durban, 2 July 2003.

47. Interviews conducted with M.J. Matjila, Durban, 11 July 2003; and S.B. Pitsoe, Durban, 17 July 2003.

48. B. Hirson, Year of Fire, Year of Ash: The Soweto Revolt: Roots of a Revolution? (Zed Press, London, 1979); and P. Kallaway (ed.), Apartheid and Education: The Education of Black South Africans (Ravan Press, Johannesburg, 1984).

49. S.B. Pitsoe, Durban, 17 July 2003. A similar point was made in an interview with M.J. Ndlovu, Durban, 14 August 2003; and in Hirson, Year of Fire, Year of Ash, p 60.

50. In terms of the 2413 medical students who graduated in Durban between 1957 and 1994, Indians graduated in the highest number, making up 1489 (or 62\%), followed by 804 Africans (about 33\%) and the much smaller number of coloured graduates (about 120 graduates or about 5\%). NRMSM Administration Office, Faculty of Medicine Annual Registrations, 1957-1994. 
were favoured somehow, when Indians passed so well and Africans failed. They were angry and bitter and felt that some mischief was going on. [The issue] of Indian bribery always surfaced ... My husband ... did not visit with Indians, nor did the others. There was no friendship as such between the students, just a working relationship only. ${ }^{51}$

Animosities between Africans and Indians were also common at the postgraduate level. In 2004, testimonies solicited for a Medical Students' Representative Council (MSRC) report revealed a great deal on this issue. ${ }^{52}$ Based on interviews conducted with students who were currently enrolled, but also former students, as well as faculty members with some institutional memory, this report captured how many Africans felt regularly belittled in front of their Indian colleagues and patients; of being ignored during tutorial sessions and ward rounds by some Indian consultants; as well as unfairly marked down in their clinical assessments by these same consultants. ${ }^{53}$ As Kgotsi Letslape asserted (with exasperation) in his 50th anniversary speech: "There's obstruction in terms of obtaining posts, there's harassment whilst in training, there's no support!" ${ }^{54}$ This lack of support also extended to employment and promotion opportunities, evident in the larger number of Indian faculty appointments made over the years. ${ }^{55}$ Encouraged by the July 2000 anniversary occasion to construct less celebratory memory narratives, one African graduate told me:

There's lot of animosity between Africans and Indians ... [Y]ou see lots of Indians stayed behind here because Durban is their home. And as such they have occupied important positions. ... [A]nd I think it creates tensions with the small group of Africans that are there who are not, who see themselves now being ruled by a new power ... [which] is black and not white. ${ }^{56}$

51. Interview conducted with B. Bolani, Durban, 1 May 1999. Another issue that caused tensions amongst students was the school's racially skewed admissions quota system, which saw larger numbers of African students accepted each year to try to rectify the country's African doctor shortage. See "Indian Accusations against Medical School Refuted", Natal Mercury, 13 November 1964. A quota system also affected admissions in the post-apartheid period to ensure alignment with wider demographic trends. This meant that many Indian students were denied admission, despite having higher marks and arguably a better chance of passing. "Matriculants Threaten to Sue Medical School", Daily News, 10 February 1995; UKZNA, "No Entry for Ms Reddy", Focus, 14, May 1999; W.E.B. Edge, "Student Selection Skewed", Daily News, 15 March 2001; "Medical School Criteria Racially Discriminating", Daily News, 12 December 2001; B. Cole, "'Not Black Enough' for Medical School", Daily News, 5 February 2004; M. Baloyi, "Prof Defends Medical School Entry System", Independent on Saturday, 3 February 2007.

52. Interviews conducted with MSRC members: A. Modiba, Durban, 4 June 2004; N. Mahlaba, Durban, 4 June 2004; and B. Hadebe, Durban, 7 June 2004.

53. A. Modiba, "Racism Report" presented on behalf of the Medical Students' Representative Council to the Faculty and Students of the University of Natal, Nelson R. Mandela School of Medicine, 26 September 2004. Similar views were expressed in the interview conducted with A. Modiba, Durban, 4 June 2004.

54. Audio-visual source: University of Natal Nelson R. Mandela School of Medicine, 50th Anniversary Banquet. A similar point was made in an interview conducted with TM, Pretoria, 21 August 2003. This doctor chose to remain anonymous.

55. Interview conducted with S.B. Pitsoe, Durban, 17 July 2003.

56. Interview conducted with MM, Durban, 28 July 2003. Similar points were raised in interviews with TM, Pretoria, 21 August 2003; S.B. Pitsoe, Durban, 17 July 2003; and KM, Durban, 14 November 2003. See also Modiba, "Racism Report" presented on behalf of the MSRC, 26 September 2004. 
A quick glance at the Faculty of Medicine's handbooks over the years confirms these points, highlighting a situation where few Africans became full professors, let alone heads of their departments, until well into the first decade of the post-apartheid years. ${ }^{57}$ Besides creating much disharmony, this sidelining process forced many Africans interested in academic medicine to leave their alma mater. While some went into private practice, others later moved into academic positions at other universities. This was evident, for example, when new institutions opened (such as MEDUNSA in the late 1970s), or when reforms at the older historically white universities from the 1980s onwards allowed black faculty and students to walk their corridors once more. ${ }^{58}$

Turning to the realm of politics, a careful analysis of archival sources, as well as post-apartheid oral interviews highlights how medical students were divided in this arena too. While apartheid era persecutions certainly did, on occasion, provide common ground that brought students together to stand in opposition to their oppressors - such as the state's attempt to phase out black students from the Medical School in the mid-1970s - students were not usually united as a group politically. ${ }^{59}$ As is the case today, medical students joined a variety of organisations with diverse political agendas in the apartheid era. For instance, while some students identified with organisations that stressed unity among all black South Africans, such as Black Consciousness organisations like the South African Students' Organisation (SASO), others supported non-racial organisations, such as the African National Congress (ANC) or the United Democratic Front (UDF). Still others identified with ethnic nationalist organisations, such as the Zulu cultural-cum-nationalist organisation, Inkatha, which was popular especially among Africans who came to the Medical School from rural Natal and the KwaZulu homeland areas.

What is more, not all students involved themselves in political activities, despite 1990s era collective "unity in adversity" and "struggle" memory narrative assertions. Some students preferred to remain apolitical so as not to be distracted from their medical pursuits. ${ }^{60}$ Even during the era when Black Consciousness organisations made headway in bridging racial divides amongst black South Africans, the defiant "black pride" ideology could still not completely unify the Medical School's student body. ${ }^{61}$ For example, by the early 1970 s, deep divisions plagued African members within SASO over the question of political co-operation

57. UKZNA, UN Calendars, Faculty of Medicine Handbooks, 1950s to 2000s.

58. Interviews conducted with M.J. Matjila, Durban, 22 September 2003; and N. Mahlaba, Durban, 7 June 2004; See also Modiba, "Racism Report" presented on behalf of the MSRC, 26 September 2004.

59. This decision was part of the state's attempt to further segregate university campuses. The 1975/76 "phase-out" plan aimed to coincide with the opening of MEDUNSA, which was being built for African students at this time. For several weeks in 1976, and again in 1977, all medical students studying in Durban boycotted lectures to protest against this "phaseout" plan, which ultimately did not occur. See "Black Students in Protest", Natal Mercury, 28 February 1976; "A Reprieve for Black Medical Course", Natal Mercury, 7 August 1976; "State Silent as Medical Students Keep up Boycott", Daily News, 8 October 1977; and "Campaign Goes on to Save Medical School", Daily News, 12 October 1977.

60. P. Govender, Questionnaire, 2003; S. Naidoo, Questionnaire, 2003; and interviews conducted with K.P. Naidoo, Durban, 4 June 2004; and Y.K. Seedat, Durban, 14 July 2003.

61. For more on the development and influence of the Black Consciousness organisation SASO - on this Medical School campus, see Noble, A School of Struggle, especially chapters 6 and 7 . 
with Indians, whom many regarded as privileged in apartheid South Africa. ${ }^{62}$ Concerns were also raised about Indian students' apparent lack of commitment to the "struggle" during this period, as one African graduate emphasised in a 2003 interview:

There were tensions between Indians and Africans, always tensions. ... I think part of it was the commitment to the struggle. I think African students were always committed to the struggle. Indian students, there were a few that were committed, but the majority were not committed to the struggle ... partly because I think they were more focused on academic things, they always did better ... in terms of performances. $^{63}$

In addition, many Indian students did not identify with SASO's inclusive definition of "black" people, which they felt placed pressure on them to replace their Indian heritage with an African one. ${ }^{64}$ Underlying uncertainties among some Indian students about whether their best interests lay in siding with Africans, or in maintaining separate identities as an intermediate group (with a few extra privileges) in apartheid South Africa, were also obstacles to student unity.

In effect, involvement in extra-curricular political activities was a risky business during the apartheid period, which could disrupt studies and threaten lives. Besides having to deal constantly with the threat of police informers who had been infiltrated into the student body to monitor students' activities, the students also had to deal with "rough" police raids, which were a frequent occurrence at Alan Taylor Residence. ${ }^{65}$ This dissuaded many from engaging in anti-apartheid activities as B.T. Naidoo asserted in his 2003 interview:

\begin{abstract}
You know as soon as you uttered something they [the police] just swatted you down or they marked you. So [some] people were very circumspect ... So this is [how] ... they silenced quite a lot of activities. ... [And] we were visited [often by the security police]. ... They would just come and ... harass your leaders ... [W]e were intimidated all the time. $^{66}$
\end{abstract}

Students who participated in protest marches were often assaulted with teargas and sometimes baton charged, while others were arrested and detained by the police. ${ }^{67} \mathrm{~A}$ few were even forced into exile because of their anti-apartheid

62. See for example, M. Mangena, On Your Own: Evolution of Black Consciousness in South Africa/Azania (Skotaville Publishers, Johannesburg, 1989), p 13.

63. Interview conducted with MM, Durban, 28 July 2003. A similar point was raised by another alumnus, KM, at an interview conducted in Durban on 14 November 2003.

64. K. Moodley, "The Continued Impact of Black Consciousness", in Pityana et al (eds), Bounds of Possibility: The Legacy of Steve Biko and Black Consciousness, pp 145-146.

65. Interview conducted with MM, Durban, 28 July 2003. Similar views were expressed in interviews with B. Maharaj, Durban, 10 June 2003; H. Philpott, Hillcrest, 14 July 2003; and V. Wilson, Durban, 6 November 2003. For corroborating documentation from the archives, see WITS, SAHA, South African Political Materials 1964-1990, Karis-Gerhart Collection, Part III Political Documents, Folder 763, South African Students Organisation (SASO), "News in Brief: Raids, Detentions, Protests", SASO Bulletin - Extra-Ordinary,1, 1, November 1971, p 2; and Folder 760, SASO, "UNB" in SASO Minutes of the National Executive Council Meeting, Alan Taylor Residence, 22-23 May 1976, p 4; UKZNA, C10/6/1-2, "Alan Taylor Residence", Council Minutes, 20 August 1976, p 110; and "Police Action at Alan Taylor Residence", Council Minutes, 18 October 1985, p 138.

66. Interview conducted with B.T. Naidoo, 10 November 2003.

67. Audio-visual source: Speech by Z. Mkhize, University of Natal Nelson R. Mandela School of Medicine, 50th Anniversary Banquet; Interviews conducted with B. Maharaj, Durban, 10 
protest activities, as was the case with Nkosazana Dlamini Zuma who later became South Africa's first minister of health in the post-apartheid period. She left South Africa as a political exile in the mid-1970s because of police harassment, and had to complete her medical degree in Britain. ${ }^{68}$ For others, political activism could draw their attention away from their academic work, producing failures or additional financial hardships through loss of bursaries and loans. ${ }^{69}$

It should also be noted that on the occasions when all students stayed away to boycott lectures, some of this was coerced support. One doctor discussed this issue with me during an early 2000s interview, once again noting discord in student ranks: "there was intimidation too ... by students towards other students" and much "pressuring [of] people" when some individuals did not subscribe to prevailing viewpoints. ${ }^{70}$ When classes were disrupted by boycotting students, students who refused to leave their classes experienced verbal or physical abuse. The archival records confirm this and are peppered with accounts of intimidation. "Offenders" were often punished by having their dorm rooms invaded by protesting students or were shamed by having their names posted on notice boards for all to see. ${ }^{71}$ Occasionally, harassment became so severe that a handful of students were even forced to abandon their studies. ${ }^{72}$ No one knew exactly what the student following was in any given period, as another medical graduate stressed to me:

There [was] never a period when all students would be involved, as politics was a dangerous game in those days ... [T]he ethos was for political freedom, and the disputes were the level [or] the tactics by which we attained [it]. So the question might be [African] students are going on boycott too often and the Indians you know complained and we wanted to write the exams and these people were preventing us. So there were numerous divisions like that...73

June 2003; and ZM, Durban, 11 September 2003; NRMSM, Administration Office, "Students in Detention", Faculty of Medicine Board Minutes, 13 March 1978, p 12.

68. S.C. Moodley, "A Personal Perspective: 1973-1995", in The University of Natal Medical School Reconciliation Graduation Booklet, p 15.

69. Interviews conducted with M. Mashego, Ashburton, 7 October 2003; and B.T. Naidoo, Durban, 10 November 2003. This was corroborated in archival material too. See for example, UKZNA, C10/8/1, "Natal Medical Students May Lose Bursaries", Rand Daily Mail, 24 October 1977; and "Boycott of Lectures at Medical School", Council Minutes, 20 June 1980 , p 5.

70. Interview conducted with Y.K. Seedat, Durban, 14 July 2003. Also see NRMSM, Administration Office, Faculty of Medicine Board Minutes, 17 August 1984, pp 1-2, which discusses the issue of intimidation amongst students.

71. Peppering Senate, Council and Faculty minutes are discussions about suitable punishments to be doled out to students who verbally and physically threatened those who did not want to participate in boycott activities. See for example, NRMSM, Administration Office, Faculty of Medicine Board Minutes, 29 May 1980, pp 3-4 and 17 August 1984, pp 1-2; UKZNA, C10/9/1, "Alan Taylor Residence", Council Minutes, 21 September 1984, p 132; "Intimidation of Students in the Medical School", Council Minutes, 16 November 1984, p 201; and "Alleged Intimidation of Students in the Faculty of Medicine", Council Minutes, 17 May 1985, p 37. Also see UKZNA, "Inquiry into Intimidation of Students by the MSRC", Senate Minutes, 21 November 1984, p 99.

72. UKZNA C10/9/1, "Faculty of Medicine, Alan Taylor Residence", Council Minutes, 21 September 1984, p 23.

73. Interview conducted with J. Coovadia, Durban, 24 June 2003. Similar points were mentioned in interviews with Y.K. Seedat, Durban, 14 July 2003; and M. Mashego, Ashburton, 14 October 2003. 
So, why was the Medical School's 50th anniversary celebration selected by alumni as the moment to air divisive and dissenting public memories about their alma mater?

Firstly, it was carefully chosen by speakers who knew that this event would draw an important crowd. Knowing that it would be well-attended by a mass audience, including medical colleagues, but also representatives from the media and ANC political dignitaries (many of whom were there to represent the government as the event doubled as the Medical School's official renaming as the Nelson R. Mandela School of Medicine), they would thus reach a wider, as well as influential, audience.

Secondly, the outpouring of similar memories after this anniversary event highlights the fact that something had shifted significantly in the broader historical context to encourage such expressions in public; expressions that stood in stark contrast to careful suppression of such memories in earlier years. Certainly, by the early 2000s, South Africa had entered a slightly later stage of its political development, with some distance from the nation-building euphoria of the early 1990s. Though still plagued by many political problems (not to mention social and economic ones), its citizens had reached an arguably more mature stage in their democracy. Feeling less pressure to fit their individual memories within unityfocused and nation-building collective frameworks, people engaged more actively in public criticisms of various aspects of their society. Nowhere was this more evident than in the fervent public criticisms made by people in regard to the actions and policies promoted under President Thabo Mbeki's government. This included, for example, its denial of the link between HIV and AIDS; its failure to condemn the deteriorating political situation under Robert Mugabe in Zimbabwe; its policies that favoured African advancement over that of other "race" groups, and its inability to solve the country's growing crime rate and poverty. ${ }^{74}$ Thus, this anniversary event and the years immediately thereafter presented an important historical opportunity to expose in public a less unified or triumphant set of memories, which had gnawed at the hearts and minds of individuals for years.

Thirdly, the speeches portray evidence of enormous frustrations around certain issues that had never been resolved, and which had continued to ferment for many years before this anniversary event. ${ }^{75}$ Dissatisfied by what common 1990s era narratives had glossed over in attempts to promote Mandela's "rainbow nation" in microcosm, those alumni speaking up in the 2000s wanted to inform the public about an institution still deeply divided by racially-inspired inequalities. Furthermore, this was not just an abstract academic exercise. The almost exclusive focus on positive aspects and celebratory achievements had contributed to the maintenance of the status quo and slow transformation at the Medical School in the post-apartheid period.

Finally, one should not forget the role played by the researcher in promoting the disclosure of alternate memories. I began my research on the history of

74. For more on historical shifts in this broader context, see for example Lodge, Politics in South Africa: From Mandela to Mbeki; and M. Gevisser, Thabo Mbeki: The Dream Deferred (Jonathan Ball Publishers, Johannesburg and Cape Town, 2007).

75. Marschall, "Pointing to the Dead", p 111. Also see Thompson, "Evidence", pp 134, 167169 and Thomson, "Anzac Memories", p 246. 
Durban's Medical School at about the same time as the 50th anniversary occasion, thus was subjectively situated within the early 2000 s South African historical context, and exposed to publications about, as well as after this anniversary event. ${ }^{76}$ This greatly influenced my thinking, as well as the way I came to read the archival records used. My location within this context also encouraged me to ask more probing questions, which in turn stimulated my interview participants to reflect more deeply about the divisions and tensions of their student days. ${ }^{77}$ As researchers, we need to be constantly aware of the power asymmetries embedded within interviewer-interviewee relationships that help "condition" the knowledge created through these encounters. ${ }^{78}$ Indeed, the researcher's particular interests; the types of questions he or she asks; and the reactions and dialogue that are generated between the interviewer and interviewee, contribute a great deal to the memories that are ultimately produced, and which are used in historical research.

\section{Conclusion}

This article has focused on the issue of memory, particularly the historically rooted and constructed nature of memories produced by alumni of Durban's Medical School. During the apartheid years, student interactions at this institution were not all rosy, despite being commonly portrayed as such in 1990s era memory narratives. The ambiguous set-up of this Medical School as "a black faculty in a white institution" ensured that students' interactions could produce commonalities, as well as unity of purpose that enabled students, at key historical moments, to stand up against their apartheid oppressors, but also ensured the continuation of deep divisions and tensions. ${ }^{79}$ A changed, more critical historical context in South Africa in the early 2000s ensured better access to alternative memory constructions about studying medicine in the apartheid era, which in turn have complicated understandings about this Medical School's history.

Of course, these alternative memories were not merely contentious windows into some remote or abstract past. Struggles over memory, particularly memories of race and racism at this institution, have had very real effects. While a number of changes have been made at Durban's Medical School in recent years, for example, in admission policies that now include more women and which are also more representative of wider demographic patterns, black students and doctors continue to study and work in an environment where many aspects of the racially defined past remain stubbornly in place. ${ }^{80}$

76. For more on how all researchers do their work from situated knowledge spaces, see D. Haraway, "Situated Knowledges: The Science Question in Feminism and the Privilege of Partial Perspective", Feminist Studies, 14, 3, Fall 1988, pp 575-599.

77. There is much scholarship on the complexities of the interviewer/interviewee relationship. Many oral historians have shown how both interviewers and interviewees are co-creators and co-producers of knowledge in interview situations. See Thompson, "Evidence", pp 137-142; D.A. Ritchie, "Introduction: The Evolution of Oral History", in D.A. Ritchie (ed.), The Oxford Handbook of Oral History (Oxford University Press, Oxford and New York, 2011); Portelli, "What Makes Oral History Different", pp 39-40; and S. Field, "Turning up the Volume: Dialogues about Memory Create Oral Histories", South African Historical Journal, 60, 2, 2008, pp 147-149, 182.

78. Moore and Roberts, "Listening for Silences", pp 319-322.

79. Moodley and Maharaj (eds), "History's Hand in the Shaping of the Medical School”, p 9.

80. For more on this, see Noble, A School of Struggle, chapter 8. 
In fact, during the first decade of the 21st century, following the 50th anniversary banquet, the general public has witnessed the activities of a number of committees appointed to explore the issue of racism at Durban's Medical School. Although certainly spurred on by this dramatic anniversary event, a broader institutional culture emphasising racial and gender transformations, not to mention employment equity, were important stimuli too. ${ }^{81}$ So was a decision taken by the Medical Students' Representative Council; a student run organisation located with an ear to the ground at the Medical School. In 2004, its executive committee felt compelled to take action to halt what its "Racism Report" labelled as the continued "lament about racis[t]" treatment and "fear of being victimised" that had carried over from the apartheid era and continued to plague Africans who studied and worked at their Medical School. ${ }^{82}$ What is more, university managers took action too. They brought in the private auditing and risk assessment firm, Deloitte \& Touche, to make in-depth inquiries by setting up a task team to look into the issue of racism at the Medical School. ${ }^{83}$

This resulted in some academics, especially senior level Indian academics, having their lives turned upside down by disciplinary hearings and suspensions while being scrutinised for alleged "racist activities" committed against both students and staff at the Medical School. ${ }^{84}$ Although eventually exonerated from these charges, the public denigration of their characters during the investigative process was serious and extreme, driving a number of Indian academics out of this institution. ${ }^{85}$ Furthermore, while these activities have ultimately opened up a limited number of posts to enable the recruitment of greater numbers of Africans at senior or management levels, the cost has been high on individuals' careers, on the high turnover rate that has ensued at the Medical School, and on a growing "culture of hostility" in the work environment that has produced much staff discontent and low morale, not to mention feelings of victimisation in the new, increasingly Afrocentric dispensation. ${ }^{86}$

81. See UKZN Archives for a selection of Annual Reports of the vice-chancellor, principal and University Council in the 1990s and 2000s period that discuss these racial, gender and employment equity transformations.

82. Modiba, "Racism Report" presented on behalf of the MSRC, 26 September 2004.

83. R. Budree and P. Ntuli, "UKZN Report Change Strategy Workshops, Nelson R. Mandela School of Medicine", 12 April 2006.

84. N. Mchunu, "Medical School Row Widens", The Witness, 8 October 2005; A. Bolowana, "Ex-Students Back Racism Report', Mercury, 10 October 2005; "Suspension of Lecturers Welcomed", Daily News, 17 October 2005; "Indo-African Race Row at South African University", www.webindia123.com, 16 October 2005; S. Beharie, "UKZN Medical School Hearings Open in a Veil of Secrecy', Sunday Tribune, 11 December 2005; Budree and Ntuli, "UKZN Report Change Strategy Workshops, Nelson R. Mandela School of Medicine", 12 April 2006; and "Medical School Students Dissatisfied", Daily News, 10 October 2006.

85. "Top Doc in Legal Battle", The Post, 8 August 2007; and "Academic Goes to Court over Racism Allegations", Legalbrief, 13 August 2007 available at http://www.legalbrief.co.za/article.php?story=20070813080503581; "UKZN Respond to Rumble", The Post, 11 June 2008; D. Potgieter, "University of Dirty Tricks", The New Age, 6 January 2012; and D. Potgieter, "Talk of Racism and Hidden Agendas", The New Age, 6 March 2012.

86. Potgieter, "University of Dirty Tricks", The New Age, 6 January 2012; T. Beaver and S. Coan, "Two UKZN Professors Suspended", The Witness, 26 April 2012; and B. Karumbidza, "All is Not Well as it Would Seem to be at UKZN", Mercury, 13 June 2012. 
While it is too soon to tell how these historical developments at the Medical School will affect memories produced by alumni in the years to come, what is obvious is that as social constructions, memories are not simple, self-evident or straightforward entities. Building on the significant work that many oral historians and memory theorists have produced in the last two or three decades, this article argues that memories are complex and fraught and deserve critical analysis. They serve particular purposes, for particular individuals or groups of people, and they are always historically-rooted entities, which can in turn shift over time. In fact, they can tell us as much about the memory creator's present, as about the past he or she is trying to convey.

Thus, as researchers, we need to remain vigilant to the contests or struggles over memories; focusing not only on what gets commonly remembered in publicly accessible narratives (as well as by whom, when and why), but we also need to consider these narrative constructions for what they omit or "forget". As seen in this article, alternative and often less agreeable memories continue to exist in the minds of individuals. Moreover, they can enter the public domain for a variety of reasons, such as when unresolved issues reach an anger or frustrationrelated breaking point in people's minds, or when more conducive historical circumstances encourage their airing. Of course, even a different line of questioning instigated by researchers can encourage alternative memory explorations. And, once unleashed, these contrary memories have the potential to seriously undermine or disrupt common memory narratives, and can have tangible effects on people's lives.

For Durban's Medical School, the focus on producing harmonious and celebratory memories - which dovetail so well with grand narratives emphasising a unified South Africa, as well as its heroic anti-apartheid "struggle" history - while inspiring to hear or read about, actually hides a great deal. Other than vastly simplifying this institution's complex history, it also blinds people to the varied and messy interactions of those who lived through a very tumultuous historical period. Instead, an analysis of both common and suppressed memories, but also a consideration of how memories shift over time, can help the historian to produce more critical, but also more interesting and multi-layered analyses of institutions. What is more, transformative actions might result from these more complex histories. Indeed, it is only when struggles over memories are celebrated - and not their sanitised, rose-tinted alternatives - that contentious issues can be discussed more openly and possibly transformed.

\begin{abstract}
The University of Natal's Medical School opened in the city of Durban in 1951 and was one of the first in the country to train black students from diverse backgrounds as doctors in apartheid South Africa. This article, however, steps back from trying to capture this school's social history, to reflect on the issue of memory, especially the constructed nature of memories produced by alumni who studied at this institution during the apartheid period. The first part of this article considers the common memory narratives produced in written and oral accounts in the 1990s. In this period, celebratory narratives that stressed students' "unity in adversity" and anti-apartheid "struggle" activities were publicly privileged and commonly remembered. However, as the second part shows, in more recent years, critical
\end{abstract}


memories have surfaced in public to challenge these triumphant narratives. In the early 2000s, memories highlighting issues of controversy and division amongst students have burst into the public domain. Reasons for these memory shifts as well as the changing historical contexts influencing their production are considered in this article. There is also an analysis of how memory production adds another critical approach for the researcher exploring institutional histories.

Key words: Durban Medical School; memory; University of Natal; production of history; apartheid; post-apartheid.

\section{Opsomming}

Die Universiteit van Natal se Mediese Skool het in die stad Durban in 1951 geopen en was een van die eerste in die land om swart studente op te lei as dokters in apartheid Suid-Afrika. Hierdie artikel beweeg egter weg van die poging om hierdie skool se sosiale geskiedenis vas te lê, en probeer om te besin oor die kwessie van geheue, veral die gekonstrueerde aard van herinneringe van alumni wat tydens die apartheid tydperk aan hierdie instelling gestudeer het. Die eerste deel van hierdie artikel beskou die gemeenskaplike geheue verhale wat in skriftelike en mondelinge vorm in die 1990's verskyn het. In hierdie tydperk is feestelike verhale wat studente se "eenheid in swaarkry" en hul anti-apartheid "struggle" aktiwiteite in die openbaar beklemtoon het bevoorreg en onthou. Maar, soos die tweede deel wys, het in meer onlangse jare, kritiese herinneringe in die openbaar verskyn wat hierdie triomfantelike vertellings uit gedaag het. In die vroeë 2000's het herinneringe wat kwessies van omstredenheid en verdeeldheid onder studente beklemtoon in die openbare domein uitgebars. Ek ondersoek die redes vir hierdie veranderinge in geheue asook die veranderende historiese kontekste wat hul produksie beïnvloed het. Verder, besin ek oor hoe die analise van die produksie van geheue nog ' $n$ kritiekelaag byvowg tot die navorser se ondersoek van institusionele geskiedenis.

Sleutelwoorde: Durban Mediese Skool; geheue; Universiteit van Natal; produksie van geskiedenis; apartheid; post-apartheid. 